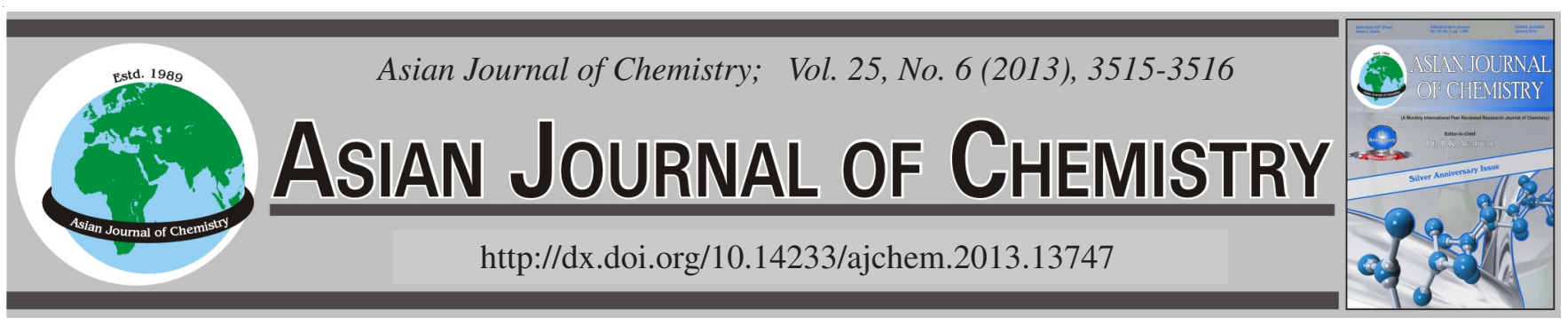

NOTE

\title{
Synthesis and Crystal Structure of tris-(1,10-Phenanthroline)-Iron(II) Dichromate Tetrahydrate, $\mathrm{Fe}\left(\mathrm{C}_{12} \mathrm{H}_{8} \mathrm{~N}_{2}\right)_{3} \mathrm{Cr}_{2} \mathrm{O}_{7} \cdot 4 \mathrm{H}_{2} \mathrm{O}$
}

\section{HaI-Xing Liu ${ }^{1, *}$, FAng-FAng Jian $^{2}$, Jing WAnG $^{2}$, Zhang-Xue Yu ${ }^{1}$, Qing-Hua Zhang ${ }^{1}$ and Xi-Shi TaI}

${ }^{1}$ College of Chemistry and Chemical Engineering, Weifang University, Weifang 261061, P.R. China

${ }^{2}$ New Materials and Function Coordination Chemistry Laboratory, Qingdao University of Science and Technology, Qingdao 266042, P.R. China

*Corresponding author: Tel: +86 53 68785095; E-mail: haixingliu@tom.com

\begin{abstract}
In this report, $\mathrm{Fe}\left(\mathrm{C}_{12} \mathrm{H}_{8} \mathrm{~N}_{2}\right)_{3} \mathrm{Cr}_{2} \mathrm{O}_{7} \cdot 4 \mathrm{H}_{2} \mathrm{O}$, was prepared by the reaction of $\mathrm{FeCl}_{2}, 1,10$-phenanthroline and potassium chromate. The asymmetric unit is composed of a $\left[\mathrm{Fe}(\text { phen })_{3}\right]^{2+}$ cation, a $\mathrm{Cr}_{2} \mathrm{O}_{7}{ }^{2-}$ anion and four water molecules. The metal centre is coordinated in a distorted octahedral mode by six $\mathrm{N}$ atoms from three 1,10-phenanthroline. The $\mathrm{Cr}_{2} \mathrm{O}_{7}{ }^{2-}$ anion is in a staggered conformation. The crystal packing is stabilized by intermolecular $\mathrm{O}-\mathrm{H} . . . \mathrm{O}$ and $\mathrm{O}-\mathrm{H} . . . \mathrm{N}$ hydrogen bonds and $\pi-\pi$ interaction.

Key Words: Crystal structure, $\mathrm{Fe}\left(\mathrm{C}_{12} \mathrm{H}_{8} \mathrm{~N}_{2}\right)_{3} \mathrm{Cr}_{2} \mathrm{O}_{7} \cdot 4 \mathrm{H}_{2} \mathrm{O}$.
\end{abstract}

Metal complexes containing diimine ligands such as 1,10phenanthroline and bipyridine are very important and widely used in analytical chemistry, catalysis, electrochemistry, ringopening metathesis polymerization and biochemistry ${ }^{1-5} \cdot 1,10-$ Phenanthroline, which is the parent for important class chelating agents, has been widely used in the construction of supramolecular architectures. Lots of phenanthroline complexs have been synthesized and reported ${ }^{6-9}$. Chromate (VI) complexes have been known as causing genotoxic and mutagenic effects in living cells, leading to development of cancer in humans. Considering the redox pathways of the carcinogenic $\mathrm{Cr}(\mathrm{VI})$ anion and the interaction of its metabolites $\mathrm{Cr}(\mathrm{V}), \mathrm{Cr}(\mathrm{IV})$ and $\mathrm{Cr}$ (III) with DNA, the lowering of its mutagenic activity has been explained by the mode of the chromate ion binding to the metal-organic ligand core ${ }^{9}$.

All commercially obtained reagent-grade chemicals were used without further purication. A mixture of $\mathrm{FeCl}_{2}(0.1 \mathrm{mmol}$, $0.02 \mathrm{~g})$, phenanthroline $(0.1 \mathrm{mmol}, 0.02 \mathrm{~g}), \mathrm{K}_{2} \mathrm{CrO}_{4}(0.1 \mathrm{mmol}$, $0.02 \mathrm{~g}$ ) and boric acid were added into $25 \mathrm{~mL}$ water with $20 \%$ $(\mathrm{v} / \mathrm{v})$ methanol and heated for $8 \mathrm{~h}$ at $353 \mathrm{~K}$. The solution was obtained by filtration after cooling the reaction to room temperature. Red sheet single crystals suitable for X-ray measurements were obtained after a few days.

The crystal structure of $\mathrm{Fe}\left(\mathrm{C}_{12} \mathrm{H}_{8} \mathrm{~N}_{2}\right)_{3} \mathrm{Cr}_{2} \mathrm{O}_{7} \cdot 4 \mathrm{H}_{2} \mathrm{O}$ (Fig. 1) is build up of one $\left[\mathrm{Fe}(\text { phen })_{3}\right]^{2+}$ cation, one dichromate anion and four dissociative water molecules. The packing diagram of $\mathrm{Fe}\left(\mathrm{C}_{12} \mathrm{H}_{8} \mathrm{~N}_{2}\right)_{3} \mathrm{Cr}_{2} \mathrm{O}_{7} \cdot 4 \mathrm{H}_{2} \mathrm{O}$ is shown in Fig. 2. The crystal data and structure refinement is shown in Table-1. The $\mathrm{Cr}$ atom is coordinated by four $\mathrm{O}$ atoms forming an tetrahedron. The bond lengths of $\mathrm{Cr}-\mathrm{O}$ are in the range of 1.615-1.800 $\AA$. The torsion angles of O4-Cr1-O1-Cr2, O7-Cr2-O1-Cr1 are 18.9(6) ${ }^{\circ}$ and $85.2(6)^{\circ}$, respectively. The $\mathrm{Fe}$ atom is coordinated by six nitrogen atoms from three 1,10-phenanthroline molecules. Six Fe-N distances range from 2.008(6) $\AA$ to 2.023(6) A. Some bond lengths and angle are shown in Table-2.
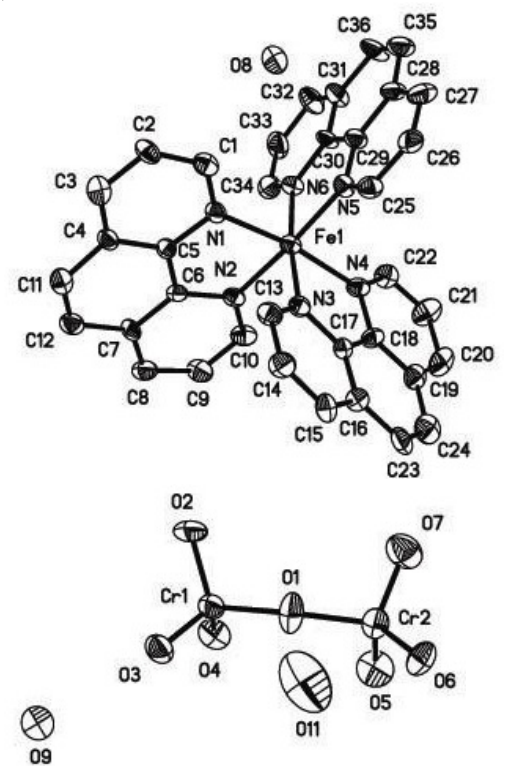

Fig. 1. Molecular structure of $\mathrm{Fe}\left(\mathrm{C}_{12} \mathrm{H}_{8} \mathrm{~N}_{2}\right)_{3} \mathrm{Cr}_{2} \mathrm{O}_{7} \cdot 4 \mathrm{H}_{2} \mathrm{O}$ with atom-labling scheme 


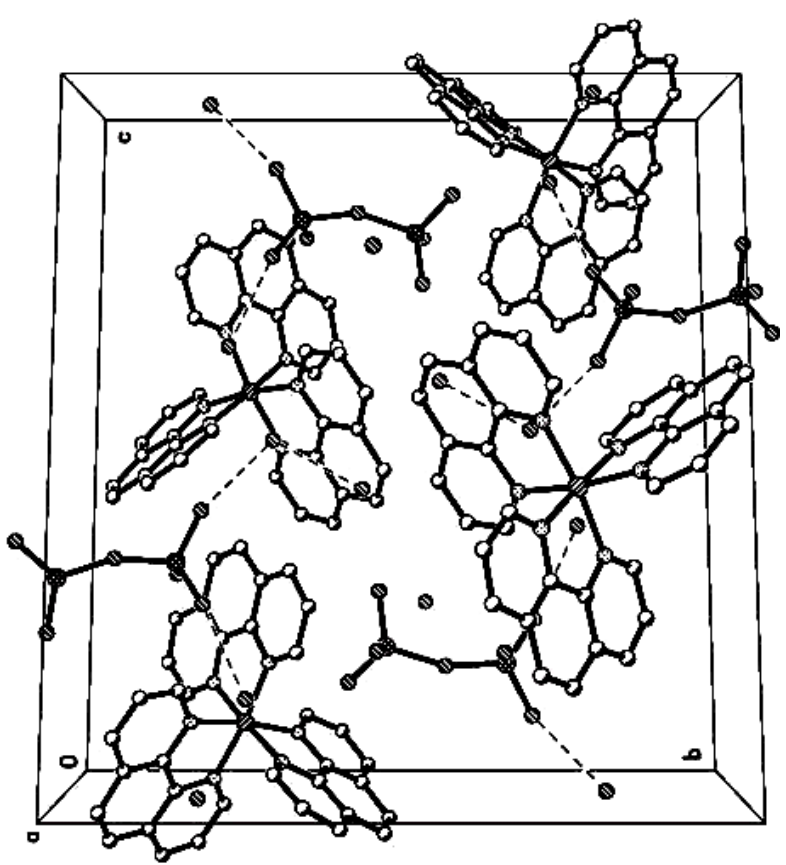

Fig. 2. Packing diagram of the title complex

TABLE-1

CRYSTAL DATA AND STRUCTURE REFINEMENT FOR 081031f

\begin{tabular}{ll}
\hline Identification code & $081031 \mathrm{f}$ \\
Empirical formula & $\mathrm{C}_{36} \mathrm{H}_{32} \mathrm{~N}_{6} \mathrm{O}_{11} \mathrm{Cr}_{2} \mathrm{Fe}$ \\
Formula weight & 884.53 \\
Temperature & $298(2) \mathrm{K}$ \\
Wavelength & $0.71073 \AA$ \\
Crystal system, space group & Monoclinic, $\mathrm{P} 2(1) / \mathrm{c}$ \\
Unit cell dimensions & $\mathrm{a}=10.4062(17) \AA ; \alpha=90^{\circ}$ \\
& $\mathrm{b}=18.457(2) \AA ; \beta=103.758(2)^{\circ}$ \\
& $\mathrm{c}=20.227(3) \AA ; \gamma=90^{\circ}$ \\
Volume & $3773.4(9) \AA^{3}$ \\
Z, Calculated density & $4,1.557 \mathrm{Mg} / \mathrm{m}^{3}$ \\
Absorption coefficient & $1.013 \mathrm{~mm}^{-1}$ \\
F(000) & 1808 \\
Crystal size & $0.30 \times 0.27 \times 0.05 \mathrm{~mm}$ \\
Theta range for data collection & 1.51 to $25.01^{\circ}$ \\
Limiting indices & $-8<=\mathrm{h}<=12,-21<=\mathrm{k}<=21,-24$ \\
& $<=1<=19$ \\
Reflections collected/unique & $19020 / 6645[\mathrm{R}(\mathrm{int})=0.1758]$ \\
Completeness to $\theta=25.01$ & $99.9 \%$ \\
Absorption correction & $\mathrm{Semi}-\mathrm{empirical}$ from equivalents \\
Max. and min. transmission & 0.9511 and 0.7508 \\
Refinement method & Full-matrix least-squares on $\mathrm{F}^{2}$ \\
Data / restraints / parameters & $6645 / 0 / 505$ \\
Goodness-of-fit on $\mathrm{F}^{2}$ & 0.864 \\
Final R indices [I $2 \sigma(\mathrm{I})]$ & $\mathrm{R} 1=0.0673, \mathrm{wR} 2=0.1173$ \\
$\mathrm{R}$ indices $($ all data) & $\mathrm{R} 1=0.1920, \mathrm{wR} 2=0.1525$ \\
Largest diff. peak and hole & 0.423 and $-0.453 \mathrm{e} . \AA^{-3}$ \\
\hline &
\end{tabular}

\section{ACKNOWLEDGEMENTS}

This study were supported by the Natural Science Foundation of Shandong Province (No. ZR2010BL025), State Key Laboratory of Inorganic Synthesis and Preparative Chemistry (Jilin University) (No. 2011-13) and MOE Key Laboratory of Analytical Chemistry for Life Science (Nanjing University) (No. KLACLS1002) and the National Science Foundation of China (No. 21171132).
TABLE-2

SOME BOND LENGTHS ( $(\AA)$ AND ANGLES $\left(^{\circ}\right)$ FOR 081031f

\begin{tabular}{lc}
$\mathrm{Cr}(1)-\mathrm{O}(4)$ & $1.615(6)$ \\
$\mathrm{Cr}(1)-\mathrm{O}(1)$ & $1.793(5)$ \\
$\mathrm{Cr}(2)-\mathrm{O}(5)$ & $1.627(6)$ \\
$\mathrm{Cr}(2)-\mathrm{O}(1)$ & $1.800(5)$ \\
$\mathrm{Fe}(1)-\mathrm{N}(1)$ & $2.008(6)$ \\
$\mathrm{Fe}(1)-\mathrm{N}(2)$ & $2.021(6)$ \\
$\mathrm{N}(1)-\mathrm{C}(1)$ & $1.337(8)$ \\
$\mathrm{N}(2)-\mathrm{C}(10)$ & $1.348(8)$ \\
$\mathrm{N}(3)-\mathrm{C}(13)$ & $1.340(8)$ \\
$\mathrm{N}(4)-\mathrm{C}(18)$ & $1.389(8)$ \\
$\mathrm{N}(5)-\mathrm{C}(29)$ & $1.375(8)$ \\
$\mathrm{N}(6)-\mathrm{C}(34)$ & $1.334(8)$ \\
$\mathrm{O}(8)-\mathrm{H}(8 \mathrm{C})$ & 0.8501 \\
$\mathrm{O}(9)-\mathrm{H}(9 \mathrm{C})$ & 0.8501 \\
$\mathrm{C}(1)-\mathrm{C}(2)$ & $1.414(9)$ \\
$\mathrm{C}(8)-\mathrm{H}(8)$ & 0.9300 \\
$\mathrm{O}(4)-\mathrm{Cr}(1)-\mathrm{O}(2)$ & $109.7(3)$ \\
$\mathrm{O}(4)-\mathrm{Cr}(1)-\mathrm{O}(3)$ & $110.5(3)$ \\
$\mathrm{O}(2)-\mathrm{Cr}(1)-\mathrm{O}(1)$ & $108.5(3)$ \\
$\mathrm{O}(3)-\mathrm{Cr}(1)-\mathrm{O}(1)$ & $107.7(3)$ \\
$\mathrm{O}(5)-\mathrm{Cr}(2)-\mathrm{O}(6)$ & $110.0(3)$ \\
$\mathrm{O}(7)-\mathrm{Cr}(2)-\mathrm{O}(1)$ & $108.2(3)$ \\
$\mathrm{N}(1)-\mathrm{Fe}(1)-\mathrm{N}(6)$ & $93.8(2)$ \\
$\mathrm{N}(1)-\mathrm{Fe}(1)-\mathrm{N}(2)$ & $82.3(2)$ \\
$\mathrm{N}(2)-\mathrm{Fe}(1)-\mathrm{N}(3)$ & $89.9(2)$ \\
$\mathrm{N}(6)-\mathrm{Fe}(1)-\mathrm{N}(4)$ & $92.3(2)$ \\
$\mathrm{C}(1)-\mathrm{N}(1)-\mathrm{C}(5)$ & $116.6(6)$ \\
$\mathrm{C}(1)-\mathrm{N}(1)-\mathrm{Fe}(1)$ & $130.7(5)$ \\
$\mathrm{C}(5)-\mathrm{N}(1)-\mathrm{Fe}(1)$ & $112.4(5)$ \\
$\mathrm{C}(6)-\mathrm{N}(2)-\mathrm{Fe}(1)$ & $111.6(5)$ \\
$\mathrm{C}(17)-\mathrm{N}(3)-\mathrm{Fe}(1)$ & $112.1(4)$ \\
\hline $\mathrm{C} r y s t$ & \\
\hline &
\end{tabular}

Crystal packing is stabilized by $\mathrm{O}-\mathrm{H} . . . \mathrm{O}$ and $\mathrm{O}-\mathrm{H} . . . \mathrm{N}$ hydrogen bonds and $\pi-\pi$ interaction

\section{REFERENCES}

1. F. Calderazzo, G. Pampaloni and V. Passarelli, Inorg. Chim. Acta, 330, 136 (2002).

2. K. Larsson and L. Ohrstrom, Inorg. Chim. Acta, 357, 657 (2004).

3. K. Binnemans, P. Lenaerts, K. Driesen and C. Gorller-Walrand, J. Mater. Chem., 14, 191 (2004).

4. P. Lenaerts, A. Storms, J. Mullens, J. D'Haen, C. Gorller-Walrand, K. Binnemans and K. Driesen, Chem. Mater., 17, 5194 (2005).

5. V. Amani, N. Safari, H.R. Khavasi and P. Mirzaei, Polyhedron, 26, 4908 (2007).

6. C.-B. Liu, J. Wang, X.-L. Zha, X.-J. Zhang, X.-Y. Li, G.-B. Che and Y.-S. Yan, J. Coord. Chem., 64, 232 (2011).

7. Y.-S. Yang, W.-X. Chai, L. Song, H.-S. Shi and L.-S. Qin, Asian J. Chem., 24, 5368 (2012).

8. M.-Q. Dong, L. Song, C. Ling and K. Xue, Asian J. Chem., 24, 1003 (2013).

9. K. Ejsmont, M. Wasielewski and J. Zaleski, Acta cryst., E58, m200 (2002). 